\title{
Seroprevalence of Capripoxvirus infection in sheep and goats among different agro-climatic zones of Odisha, India
}

Abhishek Hota ${ }^{1}$, Sangram Biswal ${ }^{1}$, Niranjana Sahoo ${ }^{1}$, Gnanavel Venkatesan², Sargam Arya², Amit Kumar ${ }^{2}$, Muthannan Andavar Ramakrishnan ${ }^{2}$, Awadh Bihari Pandey ${ }^{2}$ and Manoranjan Rout ${ }^{3}$

1. Department of Veterinary Epidemiology \& Preventive Medicine, College of Veterinary Science and Animal Husbandry, O.U.A.T., Bhubaneswar - 751 003, Odisha, India; 2. Division of Virology, ICAR-Indian Veterinary Research Institute, Mukteswar, Nainital, Uttarakhand - 263 138, India; 3. ICAR-Directorate of Foot and Mouth Disease, Mukteswar - 263 138, Nainital, Uttarakhand, India.

Corresponding author: Abhishek Hota, e-mail: dr.abhishek.ovc@gmail.com

Co-authors: SB: drsangrambiswal@gmail.com, NS: niranjanasahoo@hotmail.com, GV: gnanamvirol@gmail.com, SA: sargamarya408@gmail.com,AK: amitvet87@gmail.com, MAR: maramakrishnan@gmail.com, ABP: abpandey58@rediffmail.com, MR:drmrout@gmail.com

Received: 04-10-2017, Accepted: 16-12-2017, Published online: 26-01-2018

doi: 10.14202/vetworld.2018.66-70 How to cite this article: Hota A, Biswal S, Sahoo N, Venkatesan G, Arya S, Kumar A, Ramakrishnan MA, Pandey AB, Rout M (2018) Seroprevalence of Capripoxvirus infection in sheep and goats among different agro-climatic zones of Odisha, India, Veterinary World, 11(1): 66-70.

\section{Abstract}

Aim: The study was undertaken to assess the prevalence of antibodies to Capripoxviruses among small ruminants of Odisha, India.

Materials and Methods: A total of 500 random serum samples collected from 214 sheep and 286 goats across 10 agro-climatic zones of Odisha, were screened using whole virus antigen-based indirect ELISA for antibodies against Capripoxviruses. Results were analyzed by suitable statistical methods.

Results: Screening of 500 serum samples showed seropositivity of $8.88 \%$ and $31.47 \%$ in sheep and goats, respectively, for Capripoxviruses. The prevalence rate according to agro-climatic zone ranged from $0 \%$ (North Eastern coastal plain zone) to $48.57 \%$ (North central plateau zone) for goat pox, and $0 \%$ (Western undulating zone and North central plateau) to $22.22 \%$ (South Eastern ghat zone) for sheep pox. The difference in prevalence rates among the various agro-climatic zones was statistically significant $(\mathrm{p}<0.05)$ for goats, but not for sheep. Antibody prevalence rates among various districts were recorded to be the highest in Jagatsinghpur (30\%) for sheep pox and Dhenkanal (80\%) for goat pox.

Conclusion: The study revealed serological evidence of Capripoxvirus infection in sheep and goat populations in the study area, in the absence of vaccination. Systematic investigation, monitoring, and reporting of outbreaks are necessary to devise control strategies.

Keywords: capripox, goat pox, indirect ELISA, Odisha, seroprevalence, sheep pox.

\section{Introduction}

Infections of Capripoxviruses among small ruminants, namely, sheep pox and goat pox are OIE notifiable, acute febrile and highly contagious transboundary viral diseases [1]. Sheep pox virus (SPPV) and goat pox virus (GTPV) belong to the genus Capripoxvirus under subfamily Chordopoxvirinae in the family Poxviridae, along with lumpy skin disease virus, which is closely related to GTPV and SPPV [2]. Both SPPV and GTPV show host preference to their homologous hosts; however, some isolates have been shown to affect both the hosts [3]. The diseases are characterized by fever, coughing, salivation, arched back, oculonasal discharge, and edema of the eyelids followed by the progressive development of skin lesions all over the body. The skin lesions present as erythematous macules, vesicles, and

Copyright: Hota, et al. Open Access. This article is distributed under the terms of the Creative Commons Attribution 4.0 International License (http://creativecommons.org/licenses/by/4.0/), which permits unrestricted use, distribution, and reproduction in any medium, provided you give appropriate credit to the original author(s) and the source, provide a link to the Creative Commons license, and indicate if changes were made. The Creative Commons Public Domain Dedication waiver (http://creativecommons.org/ publicdomain/zero/1.0/) applies to the data made available in this article, unless otherwise stated. papules which ultimately develop into scabs. Lesions may also develop on mucous membranes and on internal organs, causing systemic signs such as coughing, diarrhea, depression, emaciation, abortion, and sometimes death [4]. Significant economic losses occur in terms of reduced milk yield, decreased weight gain, abortion, poor quality wool and hides, increased susceptibility to pneumonia, fly strike, and mortalities in endemic areas $[4,5]$.

Outbreaks of these diseases in Northern and Central Africa, Middle East and most of the Asian continent have become a major concern due to the huge economic losses caused [6]. In India, goat pox outbreak was first reported in the year 1936, and sheep pox was first reported in Bombay (1931-1932) and Mysore [7]. Since then, frequent outbreaks have been reported from several states in the country causing significant economic losses [1,8-10]. As reported in the annual report (NIVEDI, 2014-2015), a total of 3245 pox outbreaks occurred among sheep and goats during the year 2005-2013 in different states of India. The average morbidity and mortality rates have been recorded as $63.5 \%$ and $49.5 \%$, respectively, in the country [9]. 
As far as the North Eastern region of India is concerned, there have not been any confirmed reports of capripox outbreaks. Outbreaks and their associated risk factors including their impact on small ruminant husbandry practices have not been well documented in Odisha state. A better understanding of the current epidemiological situation of Capripoxvirus infections in the state would allow the establishment of improved disease control program that would benefit small ruminant livestock owners.

The present study was undertaken to determine the seroprevalence of sheep pox and goat pox in Odisha state, bordering Andhra Pradesh, Telangana, Chhattisgarh, West Bengal, and Jharkhand. To the best of our knowledge, this appears to be the first report on seroprevalence of sheep pox and goat pox in Odisha state, India.

\section{Materials and Methods \\ Ethical approval}

As per the committee for the purpose of control and supervision of experiments on animals guidelines, studies involving the collection of field clinical samples do not require any approval from the Institute's Animal Ethics Committee.

\section{Study areas and sample collection}

To determine the seroprevalence of Capripoxvirus infections in Odisha, a random sampling was carried out between October 2015 and April 2016. A total of 500 serum samples from 214 sheep (from 25 districts) and 286 goats (from 29 districts) were collected across 10 agro-climatic zones of the state (Table-1). The farmers/veterinarians were also interviewed to obtain the history of exposure to Capripoxvirus infections and their incidences, etc. Serum samples were collected as per the standard procedures and guidelines and stored at $-20^{\circ} \mathrm{C}$ at the Department of Veterinary Epidemiology and Preventive Medicine, C.V.Sc. and A.H., O.U.A.T., Bhubaneswar, and then sent to the Division of Virology, IVRI, Mukteswar, for testing and analysis.

\section{Indirect ELISA for detection of antibodies against Capripoxvirus}

Indirect ELISA for the detection of antibodies against goat pox and SPPV was performed as described earlier [11,12] with slight modifications. Briefly, Capripoxvirus antigen purified by $36 \%$ sucrose cushion ultracentrifugation was used as coating antigen in carbonate-bicarbonate buffer (Sigma, USA) at 1:100 dilution in place of 1:50 in modified version for ELISA in blocking buffer containing 5\% skimmed milk powder (HiMedia, India) in washing buffer (phosphate-buffered saline containing 0.05\% Tween-20). Serum samples were added in duplicates at 1:50 dilution in place of 1:100 in the modified version using blocking buffer. The plates were incubated on a shaker for $1 \mathrm{~h}$ at $37^{\circ} \mathrm{C}$. Thereafter, the plates were washed 3 times with washing buffer. Anti-goat and anti-sheep HRPO conjugates (Sigma, USA) were used at 1:12000 and 1:4000 dilutions, respectively. The plates were incubated again on a shaker for $1 \mathrm{~h}$ at $37^{\circ} \mathrm{C}$ and then washed 3 times with washing buffer. Chromogen/substrate at $50 \mu \mathrm{l}$ was added followed by incubation at room temperature for 8-10 min. Reactions were stopped by $1 \mathrm{M} \mathrm{H}_{2} \mathrm{SO}_{4}$ and results were captured with an ELISA reader at $492 \mathrm{~nm}$ (Tecan Austria $\mathrm{GmbH}$, Austria). The cutoff value set for goat pox was found to be 0.12 (twice of the value of known negative serum $+1 \mathrm{X} S \mathrm{SD})$. The OD values (mean $\pm 1 \mathrm{X}$ $\mathrm{SD})$ of the blank control reaction and conjugate control were found to be $0.097 \pm 0.002$ and $0.010 \pm 0.002$, respectively [12]. The cutoff value for sheep pox was found to be 0.130 (Twice the OD value of known negative serum $+1 \mathrm{X} \mathrm{SD}$ ). The $\mathrm{OD}$ values (mean $\pm 1 \mathrm{X}$ $\mathrm{SD})$ of blank control reaction and conjugate control were found to be $0.099 \pm 0.02$ and $0.009 \pm 0.002$, respectively [13].

\section{Statistical analysis}

The results were considered statistically significant at $\mathrm{p}<0.05$. Chi-square test using Real Statistics Data Analysis ToolPak on Excel was used to determine the difference in susceptibility of animals with respect to sex and agro-climatic zones.

\section{Results}

Out of 214 serum samples from sheep tested by i-ELISA, $8.88 \%$ were found to be positive with $11.95 \%$ and $6.56 \%$ in male and female sheep, respectively. Of 286 serum samples from goats, the overall prevalence was found to be $31.47 \%$ with $32.59 \%$ and $28.57 \%$ positivity in male and female serum samples, respectively(Table-1). Serological prevalence based on sex in both sheep and goats was found to be statistically insignificant $(\mathrm{p} \geq 0.05)$.

Odisha has a long border being shared with West Bengal and Chhattisgarh states with 10 agro-climatic zones. Among various agro-climatic zones, seroprevalence in goats varied from $0 \%$ (in North eastern coastal plain zone) to $48.57 \%$ (in North central plateau zone) (Figure-1), whereas in sheep it varied from $0 \%$ (in

Table-1: Seroprevalence of Capripoxvirus infection in sheep and goats (overall and based on sex).

\begin{tabular}{lccccccc}
\hline Species Serum Samples & \multicolumn{3}{c}{ Sheep } & & \multicolumn{3}{c}{ Goat } \\
\cline { 2 - 4 } & Male & Female & Total & & Male & Female & Total \\
\hline Total serum taken & 92 & 122 & 214 & & 135 & 161 & 286 \\
Positive (\%) & $11(11.95)$ & $8(6.56)$ & $19(8.88)$ & & $44(32.59)$ & $46(28.57)$ & $90(31.47)$ \\
$\chi^{2}$ & 1.89 & & & & 0.847 & & \\
$\mathrm{p}$ value & 0.1692 & & & 0.3574 & & \\
\hline
\end{tabular}




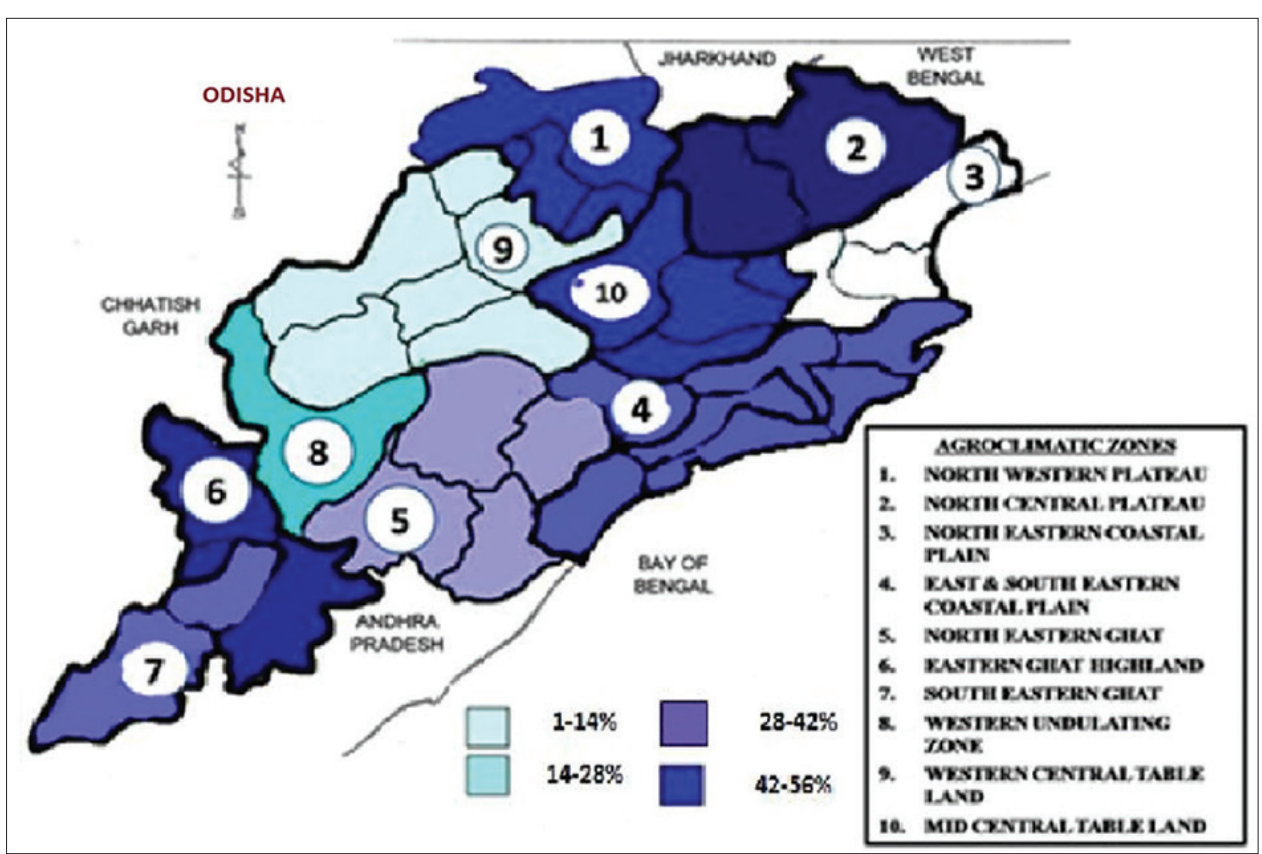

Figure-1: Variation in seroprevalence of goat pox among different agro-climatic zones.

Table-2: Seroprevalence of Capripoxvirus infection in sheep and goats based on agro-climatic zones and districts.

\begin{tabular}{|c|c|c|c|c|c|c|}
\hline \multirow[t]{2}{*}{ Agro-climatic zone } & \multirow[t]{2}{*}{ Climate } & \multirow[t]{2}{*}{ Districts } & \multicolumn{4}{|c|}{ Positive sample/total sample taken (\%) } \\
\hline & & & Sheep & Goat & Sheep & Goat \\
\hline \multirow[t]{2}{*}{$\begin{array}{l}\text { North Western } \\
\text { plateau }\end{array}$} & $\begin{array}{l}\text { Hot and moist } \\
\text { subhumid }\end{array}$ & Sundergarh & $1 / 7(14.29)$ & $3 / 10(30)$ & $1 / 16(6.25)$ & $9 / 19(47.36)$ \\
\hline & & Deogarh & $0 / 9(0)$ & $6 / 9(66.67)$ & & \\
\hline North central plateau & & $\begin{array}{l}\text { Mayurbhanj } \\
\text { Keonjhar }\end{array}$ & $\begin{array}{c}0 / 15(0) \\
-\end{array}$ & $\begin{array}{c}8 / 15(53.33) \\
9 / 20(45)\end{array}$ & $0 / 15(0)$ & $17 / 35(48.57)$ \\
\hline \multirow[t]{4}{*}{ North Eastern ghat } & & Ganjam & $0 / 3(0)$ & $1 / 7(14.29)$ & $1 / 11(9.09)$ & $12 / 38(31.57)$ \\
\hline & & Gajapati & - & $3 / 10(30)$ & & \\
\hline & & Rayagada & $1 / 8(12.5)$ & $6 / 11(54.54)$ & & \\
\hline & & Kandhamal & - & $2 / 10(20)$ & & \\
\hline \multirow{2}{*}{$\begin{array}{l}\text { Western undulating } \\
\text { zone }\end{array}$} & & Kalahandi & $0 / 9(0)$ & $2 / 11(18.18)$ & $0 / 17(0)$ & $5 / 23(21.74)$ \\
\hline & & Nuapada & $0 / 8(0)$ & $3 / 12(25)$ & & \\
\hline \multirow[t]{2}{*}{ Mid central table land } & & Dhenkanal & $2 / 8(25)$ & $8 / 10(80)$ & $3 / 16(18.75)$ & $9 / 19(47.37)$ \\
\hline & & Angul & $1 / 8(12.5)$ & $1 / 9(11.11)$ & & \\
\hline \multirow{6}{*}{$\begin{array}{l}\text { Western central table } \\
\text { land }\end{array}$} & & Bolangir & - & $0 / 10(0)$ & $1 / 19(5.26)$ & $6 / 46(13.04)$ \\
\hline & & Sonepur & $0 / 3(0)$ & $1 / 5(20)$ & & \\
\hline & & Boudh & $0 / 3(0)$ & $0 / 8(0)$ & & \\
\hline & & Sambalpur & $0 / 5(0)$ & $0 / 4(0)$ & & \\
\hline & & Bargarh & - & $4 / 11(36.36)$ & & \\
\hline & & Jharsuguda & $1 / 8(12.5)$ & $1 / 8(12.5)$ & & \\
\hline \multirow{6}{*}{$\begin{array}{l}\text { East and South } \\
\text { Eastern coastal plain }\end{array}$} & Hot and Humid & Cuttack & $1 / 9(11.11)$ & $6 / 10(60)$ & $8 / 54(14.81)$ & $19 / 50(38)$ \\
\hline & & Jagatsinghpur & $3 / 10(30)$ & $3 / 7(42.86)$ & & \\
\hline & & Kendrapara & $1 / 9(11.11)$ & $2 / 7(28.57)$ & & \\
\hline & & Puri & $0 / 11(0)$ & $1 / 10(10)$ & & \\
\hline & & Khurda & $2 / 7(28.57)$ & $4 / 7(57.14)$ & & \\
\hline & & Nayagarh & $1 / 8(12.5)$ & $3 / 9(33.33)$ & & \\
\hline \multirow{3}{*}{$\begin{array}{l}\text { North Eastern coastal } \\
\text { plain }\end{array}$} & Moist subhumid & Balasore & $0 / 14(0)$ & $0 / 16(0)$ & $1 / 39(2.56)$ & $0 / 27(0)$ \\
\hline & & Bhadrak & $1 / 10(10)$ & $0 / 11(0)$ & & \\
\hline & & Jajpur & $0 / 15(0)$ & - & & \\
\hline \multirow{2}{*}{$\begin{array}{l}\text { Eastern ghat high } \\
\text { land }\end{array}$} & Warm and humid & Koraput & $0 / 8(0)$ & $6 / 11(54.54)$ & $2 / 18(11.11)$ & $10 / 21(47.62)$ \\
\hline & & Nowarangpur & 2/10 (20) & $4 / 10(40)$ & & \\
\hline South Eastern ghat & & Malkangiri & $2 / 9(22.22)$ & $3 / 8(37.5)$ & 2/9 (22.22) & $3 / 8(37.5)$ \\
\hline$\chi^{2} p$ value & & & & & 11.8550 .22160 & 33.5150 .00001 \\
\hline
\end{tabular}




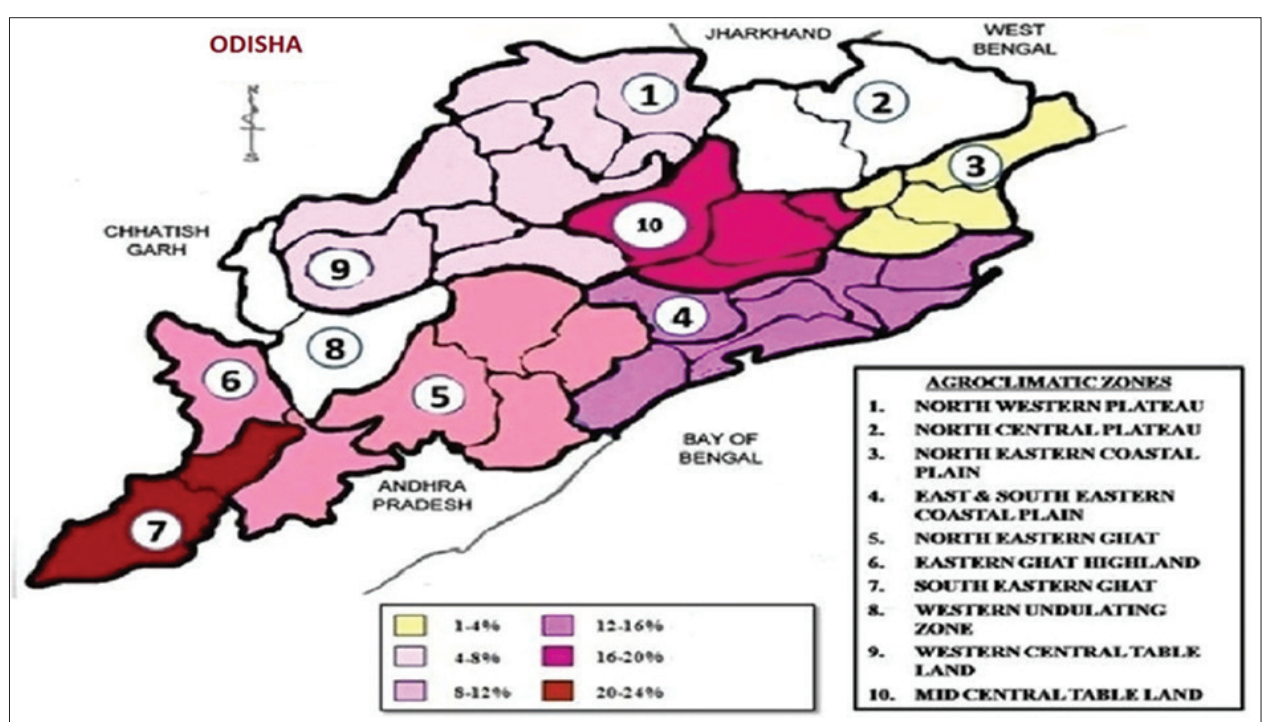

Figure-2: Variation in seroprevalence of sheep pox among different agro-climatic zones.

Western undulating zone and North central plateau) to $22.22 \%$ (in South eastern ghat zone) (Table-2; Figure-2). The differences in prevalence rates among the various agro-climatic zones were found to be statistically at a significant level $(\mathrm{p}<0.05)$ among goats, but not in sheep. Among various districts, Jagatsinghpur $(30 \%)$ was recorded with the highest prevalence among sheep, whereas samples from 12 districts (Deogarh, Mayurbhanj, Balasore, Jajpur, Puri, Ganjam, Koraput, Kalahandi, Nuapada, Sonepur, Boudh, and Sambalpur) were found to be seronegative. Similarly, Dhenkanal $(80 \%)$ was recorded with the highest seroprevalence among goats, while samples from 5 districts (Balasore, Bhadrak, Bolangir, Boudh, and Sambalpur) were found to be seronegative (Table-2).

\section{Discussion}

Sheep pox and goat pox are economically important diseases affecting small ruminants of the Indian subcontinent, Middle East, Central, and Northern Africa with adverse effects to the mutton and wool producing countries [7]. In India, the nomadic habit of sheep and goats contributes to spreading of the infection into new areas. Movement of infected animals acts as the main source of spreading the infections [5]. Transmission also occurs mechanically by the propagation of insects such as Stomoxys calcitrans and the tsetse fly through a wider geographical area [14].

Severalreports of seroprevalence of Capripoxvirus infections in India have previously been published, including one stating a $68.3 \%$ seropositivity in sheep from five northern states of India [13]. Through active (June 2007-May 2009) and passive surveillance (June 1997-May 2009), an incidence rate of $26.67 \%, 6.66 \%$, $20.00 \%$, and $46.67 \%$ for sheep pox was observed in North West agro-climatic zone of Tamil Nadu during summer, South West monsoon, North East monsoon, and winter seasons, respectively [15]. Similarly, the varied prevalence of goat pox among different agro-climatic zones has also been reported elsewhere [16].
Seroprevalence variation among sheep and goats according to agro-climatic zones as recorded in our study may be attributed to varying temperatures, humidity and rainfall, since the incidence of diseases may be influenced by climatic changes [17]. The stress resulting from climatic variations may act as a predisposing factor, as it reduces immunity to a certain extent, making the animals vulnerable to infections. The density of fly population and suitability for breeding with respect to different agro-climatic zones may also be one of the causes of variation. More numbers of capripox outbreaks are encountered during rainy season as compared to other time periods of the year [18].

Variations observed for different districts may be attributed to reasons similar to those listed above for agro-climatic zones. The results and significance of variations in both cases may change on increased sampling. The prevailing SPPV and GTPV infections in India resulted in restrictions imposed on international trade and exportation of small ruminants and their products, which in turn cause huge economic losses every year.

As no vaccination program is being carried out for these diseases in Odisha, the present study confirms the seroprevalence of Capripoxvirus infections among small ruminants due to disease outbreaks. Effective control programs demand socioeconomic and political stability, adequate infrastructure, functional veterinary services, and logistical support [9]. In India, quarantine and isolation are quite difficult due to the nomadic behavior of these animals, while stamping out and safe disposal of affected animals is also not possible. Restriction of animal movements in endemic areas with high seroprevalence, coupled with ring vaccination can significantly contribute to disease control. The vaccination strategies are considered to be the most economical and sustainable means of disease control in India [19]. Along with routine vaccination, active surveillance should be adopted at 
regular intervals to determine the spatial and temporal distribution of Capripoxvirus infections.

\section{Conclusion}

An overall seroprevalence of $8.88 \%$ sheep pox and $31.47 \%$ goat pox were recorded in the study areas with significant variations among goats in different agro-climatic zones. Since vaccination is not practiced, the results provided serological evidence of Capripoxvirus infections in sheep and goat population of the state. Further, prevention strategies must be implemented to control the infection in the small ruminant population.

\section{Authors' Contributions}

$\mathrm{SB}, \mathrm{NS}$, and AH designed the study. AH collected serum samples across the state. MR helped in communication with Pox laboratory, IVRI, Mukteswar, and improvement of the manuscript through critical reading. SA processed and performed ELISA on the samples under the supervision of GV, AK, and MAR, who analyzed and interpreted the results. The whole work could be carried out with due permission from ABP. AH wrote the manuscript under the guidance of all authors. Finally, all authors interpreted, critically revised the manuscript and approved its final version.

\section{Acknowledgments}

The authors are highly thankful to CDVOs, BVO, VAS, AVAS, and farmers who helped during sample collection across the state. This is a part of PG research program of the first author in Department of Veterinary Epidemiology and Preventive Medicine. Fund released by Dean, C.V.Sc. \& A.H., O.U.A.T., Bhubaneswar-751003, under University funds vide Letter No- 1110/CVS. Dt 22.3.2016 towards PG research of the first author.

\section{Competing Interests} interests.

The authors declare that they have no competing

\section{References}

1. Madhavan, A., Venkatesan, G. and Kumar, A. (2016) Capri poxviruses of small ruminants: Current updates and future perspectives. Asian J. Anim. Vet. Adv., 11: 757-770.

2. King, A.M.Q., Adams, M.J., Carstens, E.B. and Lefkowitz, E.J. (2012) Virus Taxonomy - Ninth Report of the International Committee on Taxonomy of Viruses. Academic Press, San Diego, CA. pp291-309.

3. Babiuk, S., Bowden, T.R., Parkyn, G., Dalman, B., Hoa, D.M., Long, N.T., Vu, P.P., Bieu, D.X., Coops, J. and Boyle, D.B. (2009) Yemen and Vietnam Capripoxviruses demonstrate a distinct host preference for goats compared with sheep. J. General Virol., 90: 105-114.

4. Bowden, T.R., Babiuk, S.L., Parkyn, G.R., Copps, J.S. and Boyle, D.B. (2008) Capri poxvirus tissue tropism and shedding: A quantitative study in experimentally infected sheep and goats. Virology, 371: 380-393.

5. Mirzaie, K., Barani, S.M. and Bokaie, S. (2015) A review of sheep pox and goat pox: Perspective of their control and eradication in Iran. J. Adv. Vet. Anim. Res., 2(4): 373-381.

6. Babiuk, S., Bowden, T.R., Boyle, D.B., Wallace, D.B. and Kitching, R.P. (2008) Capri poxviruses: An emerging worldwide threat to sheep, goats and cattle. Transbound. Emerg. Dis., 55: 263-272.

7. Rao, T.V.S. and Bandyopadhyay, S.K. (2000) A comprehensive review of goat pox and sheep pox and their diagnosis. Anim. Health Res. Rev., 1(2): 127-136.

8. Venkatesan, G., Balamurugan, V., Singh, R.K. and Bhanuprakash, V. (2010) Goat pox virus isolated from an outbreak at Akola, Maharashtra (India) phylogenetically related to Chinese strain. Trop. Anim. Health Prod., 42: 1053-1056.

9. Bhanuprakash, V., Hosamani, M. and Singh, R.K. (2011) Prospects of control and eradication of capripox from the Indian subcontinent: A perspective. Antiviral Res., 91: 225-232.

10. Venkatesan, G., Balamurugan, V. and Bhanuprakash, V. (2014) Multiplex PCR for simultaneous detection and differentiation of sheeppox, goatpox and orf viruses from clinical samples of sheep and goats. J. Virol. Methods, 195: 1-8.

11. Hosamani, M., Nandi, S., Mondal, B., Singh, R.K., Rasool, T.J. and Bandyopadhyay, S.K. (2004) A vero cell-attenuated goat pox virus provides protection against virulent virus challenge. Acta Virol., 48: 15-21.

12. Bhanuprakash, V., Hosamani, M., Juneja, S., Kumar, N. and Singh, R.K. (2006) Detection of goat pox antibodies: Comparative efficacy of indirect ELISA and counterimmunoelectrophoresis. J. Appl. Anim. Res., 30: 1777-1180.

13. Bhanuprakash, V., Saravanan, P., Hosamani, M., Balamurugan, V., Mondal, B. and Singh, R.K. (2008) Status of sheep sera to bluetongue, peste des petits ruminants and sheep pox in a few northern states of India. Vet. Ital., 44(3): 527-536.

14. Tuppurainen, E.S.M., Venter, E.H., Shisler, J.L., Gari, G., Mekonnen, G.A., Juleff, N., Lyons, N.A., De Clereq, K., Upton, C., Bowden, T.R., Babiuk, S. and Babiuk, L.A. (2017) Review: Capripoxvirus diseases: Current status and opportunities for control. Transbound. Emerg. Dis., 64: 729-745.

15. Selvaraju, G. and Balasubramaniam, G.A. (2014) Temporal trends of peste des petits ruminants, bluetongue and sheep pox in North-West agroclimatic zone of Tamil Nadu. Indian Vet. J., 91(9): 39-41.

16. Sajid, A., Chaudhary, Z.I., Sadique, U., Maqbol, A., Anjum, A.A., Qureshi, M.S., Hassan, Z.U., Idress, M. and Shahid, M. (2012) Prevalence of goat pox disease in Punjab provinces of Pakistan. J Anim. Plant Sci., 22 Suppl 2: 28-32.

17. Moenga, B., Muchemi, G., Kangethe, E.K., Kimenju, J.W., Mutiga, E.R. and Matete, G.O. (2016) Impact of climate change on the incidences of small ruminant diseases in a pastoral area of Kenya. Afr. J. Agric. Res., 10(27): 2389-2396.

18. Garner, M.G., Sawarkar, S.D., Brett, E.K., Edwards, J.R., Kulkarni, V.B., Boyle, D.B. and Singh, S.N. (2000) The extent and impact of sheep pox and goat pox in the state of Maharashtra, India. Trop. Anim. Health Prod., 32: 205-223.

19. Bhanuprakash, V., Hosamani, M., Venkatesan, G., Balamurugan, V., Yogisharadhya, R. and Singh, R.K. (2012) Animal poxvirus vaccines: A comprehensive review. Expert Rev. Vaccines, 11: 1355-1374. 